\title{
Understanding Draupadi as a paragon of gender and resistance
}

\author{
Motswapong, Pulane Elizabeth \\ University of Botswana \\ motswaponge@ub.ac.bw
}

\begin{abstract}
In this article Draupadi will be presented not only as an unsung heroine in the Hindu epic Mahabharata but also as a paragon of gender and resistance in the wake of the injustices meted out on her. It is her ability to overcome adversity in a venerable manner that sets her apart from other women. As a result Draupadi becomes the most complex and controversial female character in the Hindu literature. On the one hand she could be womanly, compassionate and generous and on the other, she could wreak havoc on those who wronged her. She was never ready to compromise on either her rights as a daughter-in-law or even on the rights of the Pandavas, and remained ever ready to fight back or avenge with high handedness any injustices meted out to her. She can be termed a pioneer of feminism. The subversion theory will be employed to further the argument of the article. This article, will further illustrate how Draupadi in the midst of suffering managed to overcome the predicaments she faced and continue to strive where most women would have given up.
\end{abstract}

Key words

Draupadi; marriage; gender and resistance; Mahabharata and women

\section{Introduction}

The heroine Draupadi had many names: she was called Draupadi from her father's family; Krishnaa the dusky princess, Yajnaseni-born of sacrificial fire, Parshati from her grandfather side, panchali from her country; Sairindhiri, the maid servant of the queen Vitara, Panchami (having five husbands)and Nitayauvani,(the every young) (Kahlon 2011:533). In the epic Mahabharata she has not been celebrated in the same way as her 
counterpart Sita ${ }^{1}$ in the Ramayana. In spite of that, this article maintains that Draupadi is a very powerful woman who should be given the same recognition like Site. The article will first of all introduce Draupadi as a mythological figure in her past life and after rebirth, where the story and her marriage to five brothers is developed. Furthermore, Subversion Theory will be adopted as a theoretical framework, and lastly the paper will argue that Draupadi is a paragon of gender and resistance through a rereading the narrative of Draupadi.

\section{Draupadi: Her life}

Before presenting Draupadi as a paragon of gender and resistance, her story will be briefly outlined to familiarise the reader with the heroine of Epic of Mahabharata. Saptorshi Das (2014:224) sees Draupadi as one of the most prominent and exceedingly interesting characters within one of Hindu Mythology's greatest magnum opuses of all times, namely the Mahabharata. Similarly, Preeti Chaudhary (2014:17) describes Draupadi as not a human but a super human, who is also worshipped as a cult Goddess in many temples of south India. The story will be outlined in such a way that Draupadi is introduced both in her previous life and after her rebirth when the story is set.

According to Narayana Pillai (1988), in her past life:

Draupadi had been born as Nalayani, the wife of a powerful sage Maudgalaya. Maudgalaya suffered from leprosy, however Nalayani serves him dutifully and without complaint. One day while eating, Maudgalaya's finger fell into the food; Nalayani however quietly removed the finger and continued eating, the food for her tasting as sweet as honey (Pillai 1988:138-139).

Maudgalya was pleased with her devotion and granted her a boon. Nalayani requested that he takes the form of many beings and fulfil her sexual wishes and desires. Her wishes and desires were granted and the two continued to

1 Sita is a heroine of Ramayana. Her conduct and character not Draupadi is regarded as normative in Hindu Society. She maintains throughout most of her ordeal a submissive acquiescence to the whims of her often cruel husband Rama. Finally, rather than re-join him, she abandons her life and is swallowed by the Earth, her mother. For a full detailed story of Sita (see Uttara Kanda Canto 1 of Valmiki Ramayana) 
live in bliss for a very long time until it was time for Maudgalya to renounce the world. Nalayani "was distraught and wanted to know where she was going to seek pleasure (that is sexual pleasure) from then on. Maudgalya was exasperated by her unbridled lust and cursed her" (Pattnaik 2010:92): that "she would be born as a prostitute, the wife of five men" (Pillai 1988: 138-139).

Since the Gods have ordained a maximum of three husbands for a woman, and Draupadi has many husbands and according to the shastras ${ }^{2}$ of the age, she can be considered a characterless women nameless and stripped of her dignity by being derided by Duryodhana as "that women with five husbands" which suggests some moral and sexual deviance in her family situation. The moral condemnation appears to those who taunt her to justify their treatment of her to use her as they choose.

\section{Draupadi's life after rebirth}

Draupadi is daughter of King Drupada in the epic of Mahabharata ${ }^{3}$. For many years Drupada, the king of Panchala had no children. So to have children he performed tapas (austerities). He thought only of God day and night and prayed to him. God blessed him, and two children were born out of the haven fire lit by Drupada, here to fulfil his determination of vengeance against Dronacharya, his enemy, through death. The first to emerge out of the holy pyre was a son called Dhristadyumna, and the second a daughter called Draupadi. She was extremely beautiful, intelligent and virtuous women, with her body smelling like fresh bloom lotus. There were only a few women in Hindu Mythology who were aggressive and who spoke their mind in the world of men. Draupadi was one of them. She is considered by many as the first feminist of Hindu Mythology. At time of her birth, a celestial voice had proclaimed, that this unparalleled beauty has taken birth to uproot the Kauravas and establish the rule of religion (Ganguli 1990).

2 This is a Sanskrit word that means 'precept, rules, manual, compendium, book or treatise' in a general sense. The word is generally used as a suffix in the Indian literature context, for technical or specialized knowledge in a defined area of practice. Available: https://en.wikipedia.org/wiki/Shastra.

3 For a full and detailed story of Draupadi read Mahabharata Book I and II. [Online] Available: http://larryavisbrown.homestead.com/files/xeno.mahabsynop.htm 
There was war between Draupada and Arjuna. Arjuna won and left Draupada humiliated by taking half his kingdom. When it was time for Draupadi to get married her father, who had wanted only Arjuna to wed his daughter, set a swamyavara (marriage by self-choice) with the hope of bringing Arjuna to the wedding and out of his hiding. The participants in the swayamvara had to shoot an arrow at a revolving target, while looking at its reflection in a bowl of water kept under it. Drupada knew that only Arjuna would be able to accomplish this task. Arriving with his brother disguised as Brahmins (Priestly class), Arjuna successfully hit the target, winning Draupadi's hand in marriage.

As soon as the brothers arrived home with Draupadi, they asked their mother, Kunti, to take a look at what they had brought home. Without looking, she asked them to share it equally among themselves. This was not strange because the brothers usually share the bhiksha (alms) they received every day. In order to obey their mother's order, the five Pandavas brothers accepted Draupadi as their wife, without discussing it with her or asking for her consent.

\section{The game of ice}

Shakuni (Yudhisthira's cousin) had always wanted to bring his cousin down. Together with his brother's friend Karna and maternal uncle called the Pandavas to a place called Hastinapura to play a game of dice. Shakuni was skilled at winning by unfair means. The plan was that Shakuni would play against Yudhishthira and win the game, since it was impossible to win at the battlefield. The game of dice began and Yudhishthira gradually lost all his wealth and kingdom in the stakes. He went on to put each of his brothers at stake and lost them too. Ultimately he put himself at stake and lost again. All the Pandavas were now the dasas (servants) of Kauravas. But Shakuni told Yudhishthira that he had not lost all yet, that he still had Draupadi with him. He also told him that he could try and win it all back by putting Draupadi at stake. To the shock of all present there, Yudhishthira put Draupadi as a bet for the next round. Shakuni won this round too and Duryodhana commanded his younger brother Dushasana to present Draupadi at the forum. Dushasana barged into Draupadi's living quarters. She was clad merely in one piece of attire and was menstruating. She begged him not to take her to the sabha (court) filled with dignitaries. But Dushasana grabbed her by the hair and presented her into the court. 


\section{Draupadi's disrobing}

Draupadi repeatedly questioned the right of Yudhishthira to place her at stake when he himself has lost his freedom in the first place. No one could give her answer. Then to the horror of everybody present Duryodhana ordered his brother to strip Draupadi of her sari. Dushasana proceeded to obey the order and starts disrobing Draupadi. On the realization that her husbands were unable and unwilling to come to her rescue, Draupadi started praying to Krishna to protect her. Krishna answered her prayer and a miracle occurred in front of everyone's eyes. Instead of being stripped naked, Draupadi's sari kept getting extended as Dushasana unwrapped layers and layers of it. In the meantime, Draupadi was lost in prayer and was oblivious of her surroundings. Finally, an exhausted Dushasana gave up his effort and fell to the ground. This way, Draupadi was protected from being humiliated in front of the entire congregation.

\section{Subversion as a theoretical framework}

The Feminist theory of subversion will be employed in the article to further the discussion. Subversion is the act of undermining patriarchal institutions. To subvert something is to take oppressive forces and turn them into something that challenges the oppressor. Feminist scholarship (Mukherjee 2016, Chaudhary 2014, Chakravorty 2016) unitedly refer to the experiences of Draupadi, especially the disrobing incident, as an illustration of the ways in which such a discourse has constructed and perpetrated the idea of the woman's body being the site on which male hegemonic structures operate. Since a woman's honour is presumed to reside in her violated body, its violation through public stripping means that she loses the honour both of herself as an individual, as well as a group family or even the nation which she belongs. Subversion becomes apparent because first of all polyandry maybe seen as a subversion of patriarchal norm of a patriarchal society; although she is very uncomfortable she gives her consent thinking of a great good (Mukherjee 2016).

In Mahabharata Draupadi's disrobing is a culmination of dishonouring of the Pandavas. Her acts upset the oppressors' carefully laid plans for her subjugation. By refusing to acknowledge her 'dishonour' she also refuses to acknowledge their 'manhood'. Her resistance lies in subverting the whole construct of equating feminine honour and purity with an inviolate 
body. Draupadi articulates the narrative of resistance on many levels, and therefore she becomes no only powerful but also complex. She achieves a subversion of a mythical Draupadi story while at the same time endangering the stabilities of the gender hegemonies. She resists her oppressor through defiance, anger and courage because she has suffered outrageous attacks on her body and spirit. She becomes a feminist figure because she is able to subvert the objectification and commodification of women in society. It is her stri-shakti (power of woman) which is manifested when she comes out unscathed during the disrobing episode.

Draupadi raises her voice against extreme torture and atrocities inflicted on her, such that at the end she redefines herself. She refuses to remain the object of male narrative, but asserts herself as 'subject' and emphasises the truth her own presence and constructs a meaning. Through subversion she becomes that which resists 'counter' male knowledge, power and glory. By so doing Draupadi rejects the binary structures of patriarchal discourses of the political social and ideological forces of the society, hence subverting commodification in the society and foregoing her identity as a human, not a commodity.

\section{Reading Draupadi's narrative as a paragon of gender and resistance}

Draupadi is one of the most celebrated heroines of Indian epic Mahabharata, ${ }^{4}$ which together with Ramayana ${ }^{5}$ are cultural credential of the so-called Aryan Civilization. Sita, not Draupadi, is one of the best known examples of a Goddess being held up as a paradigm for women in a culture obsessed with marriage, in which 'she is presented as the role model of the ideal,

4 One of the two major Sanskrit epics (the other being Ramayana) of ancient India, was attributed to Kṛṣna Dvaipāyana Vyāsa. The Mahabharata is an epic narrative of the Kurukshetra war and the fates of the Kaurava and the Pandava princes. It dates back to $1600 \mathrm{BC}$ and is considered the world's longest poem, the original epic consists of 100,000 stanzas in verse structured 18 books. (cf. Narayana 1988, vii).

5 This is the first ancient Indian heroic epic poem traditionally ascribed to the Hindu muni (sage) Vālmīki The epic narrates the life of Rāma, a legendary rāja-kumāra (prince) of Kośala; his banishment from his kingdom by his father king Daśaratha, his travels across forests in India with his wife Sìtā and brother Lakșmaṇa, the kidnap of his wife by his enemies, resulting in a war with Rāvaṇa (the king of the island of Lanikā), and eventual return to Ayodhya to be crowned king. 
selfless, submissive wife (pativrata) who is expected to remain faithful and devoted to her husband, no matter how badly she is treated' (Kinsley, 1986:79-78). This article maintains however that Draupadi should also be given the same prominence accorded to Sita, despite being married to five husbands. Whereas Sita maintains her silence when ill-treated by her husband, Draupadi does not. She is vocal and laments the despicable treatment she gets from the males in the story. She had grown up to be an aggressive woman who spoke her mind in a world where women would silently suffer than speak. Draupadi, therefore is a force to be reckoned because:

... If Mahabharata is an intricately women saga of hatred and love, bloodshed and noble thoughts, beauty and gentleness, victory and defeat, then Draupadi is its shining jewel, casting the shadow of her towering personality over the epic poem and the all destroying war described (Das 2014: 231).

Preeti Chaudhary (2014) describes Draupadi as "not a human ... a super human, worshipped as a cult Goddess in many temples of South India". She has firm determination and unbending will, making her "proud and angry heroine of the epic Mahabharata who has remained an enigmatic woman of substance" (Chaudhary 2014:17). Therefore Draupadi becomes an image of empowering women because of her strong will power, brilliant intellectuality and pride which mark her as a dignified woman different from other women like Sita who expressed softer feminine qualities. It must be noted that there are few women in Hindu mythology who were aggressive and who spoke their mind in a world of men. Draupadi was one of those few. That is why she is considered by many as the first feminist of Indian mythology because of her resilience, and nonconformity to male dominated religious hierarchy (Ganguli 1990). Her unpopularity, therefore has to do with the fact that her image does not encourage women to conform to the requirements of an Indian patriarchal society. Subsequently, Draupadi becomes a paragon of gender and resistance.

It is worth noting that while polyandry was pretty much accepted during the time of Mahabharata, it was regarded with much censure in the era of the epic. Hence Draupadi was much looked-down-upon for having married the five Pandava brothers. In fact, Karna during the game of dice had addressed her as veshya or prostitute for having several husbands. She 
was neither the perpetrator of this social transgression nor did she enter into a polyandrous contract of her own accord. She had given her heart to the noble Arjuna at her swayamvara (marriage by self-choice). The intricate web of polyandry that she got entangled in, had been bestowed upon her by destiny. There is no reason, whatsoever to thrust the fault of transgression on her. Incidentally, though the matter of polyandry was so controversial, Draupadi is also regarded as one of the five srestha (or the most chaste) Naris. This in itself is an anomaly and cannot be properly explained.

\section{Draupadi within the patriarchal context}

The portrayal of Draupadi in the epic leaves so much to be desired that is why she is conceived by most as insignificant. However, it worth noting that Draupadi can be seen as an unsung heroine of the epics. Notwithstanding, there are women characters in both Ramayana and Mahabharata who have not been given platform to exist independently. Chitra Banerjee (2009) echoes that sentiment very well by lamenting about 'powerful women' in the epics who have remained shadowy figures, and whatever their thoughts and emotions are seen as inexplicable. These women are only brought to the fore when they concede with the lives of the male heroes, ultimately rendering their roles as subservient to those of their fathers, husbands, brothers and sons.

In addition, within a masculine and patronymic context, Draupadi is exceptional, indeed single in the sense of cold, unpaired and detached. She provides the occasion for the violent transaction between men, the efficient cause of the crucial battle (Spivak 1981). Her eldest husband is about to lose her by default in the game of dice. He had staked all he owned and Draupadi belonged within that all (Mah.65:32). Furthermore, even though Draupadi is strong, spirited and an outspoken woman she is still very faithful to the five brothers. Alleyn Diesel (2002) compares her to Helen of Troy where she is "regarded by many men as a prize, valuable object to be competed for and squabbled over, and she becomes the central reason for internecine conflict, which brings disorder (adharma) and devastation to society" (Diesel 2002: 9).

By the same token, Draupadi's strange civil status seems to offer grounds for her predicament and non-recognition as well. Since "the scripture prescribed 
one husband for a woman, Draupadi is dependent on many husbands, she can be designated as 'a prostitute'. Therefore, there is nothing improper in bringing her clothed or unclothed into the assembly' (Mah. 65:35-36). In the epic Draupadi's legitimized pluralisation (as a wife among husbands in singularity as a possible mother or harlot) is used to demonstrate male glory. Karna for instance, publicly called Draupadi a whore for being a wife of five men. Despite all these horrific experiences, Draupadi is not in the least deterred by the harsh treatment she receives from the males in the story. If anything these experiences of ill-treatment empower her, hence driving her to be even stronger and resilient. She continues to display her individuality, strength and unyielding determination for both justice and vengeance, hence becoming an empowering character.

Throughout her life Draupadi had to undergo humiliation, abuse and deprivation. Though unjustly treated and hence a very angry woman, Draupadi draws from her purity, gained over male intimidation and violence, and thus brought healing to communities. These "translate the ultimate victor of women's strength" (Diesel 2002: 10). This does not deter Draupadi to be resilient as she continued to resist male dominance. The resilience is discussed under the themes below:

\section{(a) Women as properties or possessions of men}

When the five brothers arrive at the household, they ask their mothers to come and see what they have brought from their outing. The mother without knowing instructs the brothers to share amongst them equally. There is no doubt that there seems to be total ownership over Draupadi as a daughterin-law, a wife and a mother. This is evident in the way (even though some might argue that Kunti was not aware that her sons had brought Draupadi) that she innocently assumed it was the usual alms her sons brought daily to the homestead. Even so there is no justification as to why the sons decided to follow their mother's instruction without questioning it. The answer is obvious. Draupadi does not have a say in the whole saga simply because she is viewed as a possession. Hence the sons did not see the need to alert their mother that this time around they had brought somewhat different alms to be shared equally.

Consequently, Draupadi becomes a possession of five husbands even though she had chosen her real husband during the swayamvara. One 
cannot but wonder what the purpose of the swayamvara was if at the end of the day it is not taken into consideration. Actually the swayamvara is also doubtful in the way it was conducted. In a proper swayamvara, the kanya (daughter) gets to choose her husband by herself, yet in the case of Draupadi the father King Draupada arranges the swayamvara because he wants Arjuna (his choice) to come out of his hiding. It is worth noting that matters affecting women directly are never shared with them or any consent given. Significantly, Draupadi questions their behaviour: "is a woman her husband's property? Is she an object that can be gambled?" (Mankekar 1993:474). The fact that Draupadi has been given to the five brothers by their mother makes her their property, hence she can be gambled. Draupadi further questions the dharma (religious duty) of the kings especially those present in the assembly. Her words are not just a plea of a humiliated and helpless woman, but a challenge to the knowledge of right and wrong of the kings. By questioning the behaviour of her husband as well as the dignitaries present, Draupadi is challenging the normative, something which was unheard of during the time of the Mahabharata. In other words she was disrupting the order reigning in the (Sabha) court because she was rebelling against the norm, hence the subversion. This was a step unimaginable for a woman of her time and setting. Das (2014:228) sees Draupadi's question:

not as an antiquated question of the wronged virtuous queen whose integrity has been put on stake, rather it holds as much importance and relevance because it is a question of the protection of those who find themselves unprotected by a system in a court full of the most powerful kings of the time, here was a woman who dared to stand for herself and speak up, aloud, against male perpetrated injustices.

\section{(b) Paradigm of pativarta (ideal wife) in a matrimonial polyandry}

Despite Draupadi suffering at the hands of five husbands, (the only case of matrimonial polyandry in The Mahabharata), she is expected to service her five husbands without any complaints. By being in the company of five husbands, Draupadi becomes a possession, yet the expectation is that she should be a pativrata (an ideal wife). Let it be made clear that polyandry was not an alien concept in ancient India because it has been mentioned even in the Vedas (Neelakantan 2013). Although the practice has been 
alluded to in the Vedas, the Kama Sutra ${ }^{6}$ as well as the sutras ${ }^{7}$ and smritis ${ }^{8}$, it is not confined to Hinduism, it was also found in Jain and Buddhist texts confirming that it was not a foreign practice at the time (Singh 1978).

Although views might be diverse some theories endorse the strengthening of the patriarchal society of ancient India by the sporadic shift from a more standard form of polyandry to the type of fraternal polyandry witnessed in the Mahabharata (Nabar \& Shanta 1997). Aarathi Ganesan (2014) is quick to point out that simply "mentioning the practice is not analogous to its actual practice in Indian society," for the same reasons that its occurrence "in the Mahabharata is almost innocently incidental and most importantly singular" (Ganesan 2014: 9). She is to be a submissive wife and mother. By maintaining her silence until a point when she is pushed to a corner, Draupadi is actually upholding not only her honour but that of her family and her community as well. Failure to honour might incur repercussion as a pativrata. On relationship with her husbands, Bhawalkar (2002:143) says "Draupadi was not a dumb follower of her husbands. She had her own individuality. Though soft speaking she used harsh words to her husbands and others when necessary". It is because of this uniqueness that the Pandavas often looked to Draupadi for guidance and approval.

\section{(c) Denied motherhood, lost motherhood}

Motherhood defines a woman in Indian cultures. Therefore, it follows that a woman becomes fully recognised and accepted by the family and community because she has produced a child or an heir. In India there is still an emphasis on producing an heir who is a boy, for various reasons:

6 Doniger (2003: i) defines The Kamasutra is the oldest extant Hindu textbook of erotic love. It was composed in Sanskrit, the literary language of ancient India, probably in North India and probably sometime in the third century.

7 Sutra is a type of religious literature present in many Asian traditions such as Hinduism, Jainism and Buddhism. The word sutra is a Sanskrit term that means 'discourse' (in the Pali language: sutta). Another meaning suggested for the word sutra is 'threads'. Sutras were originally oral traditions and designed to prompt the memory, which was probably the best alternative in a context where the majority of the population was illiterate (Available: https://www.ancient.eu/Sutra/)

8 O'Flaherty and Doniger (1988: 2-3), defines Smriti as literally "that which is remembered" are a body of Hindu texts usually attributed to an author, traditionally written down but constantly revised, in contrast to Śrutis (the Vedic literature) considered authorless that were transmitted verbally across the generations and fixed. 
for example, to keep the family name alive, to perform ritually during his father's cremation to mention, to name but a few. It is because of the importance of having children that it is believed in this culture that children cement the relation between husband and wife and their respective families. This explains why Draupadi in the midst of her suffering decides to stay in the marriage rather than go back to her natal home. This is partly because she did not want to shame her natal family by returning, and but (most importantly) she wanted to be with her five sons and raise them instead of abandoning them. In other words, she had to forgo her freedom for the sake of staying and raising her children. This is what I refer to as denied motherhood, lost motherhood.

\section{(d) Humiliation vs shaming}

The humiliation, the pain and shaming that Draupadi has to undergo during her stay at in the marriage is beyond comprehension. The highlight of this unacceptable and atrocious treatment comes at a time when she is dragged to her court by her hair and disrobed. She was subject to horrific indignity, being ogled at while wearing a garment stained with her menstrual blood (Ganesan 2014:19). She is disrobed in front of a group of men. She is humiliated because she is seen as a "prostitute, a servant of the Pandavas and therefore they are free to do as they please with her". Devdutt Pattanaik (2010) maintains that "Karna calls Draupadi a whore, stating that the law only allows a woman to lie with four men and she married five men, [and] is to be treated without dignity, effectively as a piece of public property' (Pattanaik 2010:146).

If one looks closely at why she has to undergo such unimaginable torture, we are told it is for the glory of men. This is unacceptable because Draupadi finds herself in the predicament in the first place because of the men. She had done everything right by marrying a man of her choice, yet she finds herself married to five men and is called names, something out of her control. However, it can be argued that her status after the game of dice facilitated such an incident, and her current societal position placed her in a position of being unable to disobey order (Dhavalikar 1991). It is worth noting that the very same men who put her in this situation turn around and humiliate her. Despite all the shame and humiliation meted to her Draupadi stood her ground and survives and in fact he tables are 
turned when the shame and humiliation is diverted to the men in the sabha (court).

\section{Draupadi: war of justice and resistance}

Despite the humiliation that Draupadi had to undergo. Seeing that she is at the mercy of the men in the sabha (court) and seeing that her husbands were not going to rescue her. She calls on Krishna to intervene. By evoking Krishna, Draupadi exercises what could be called war of justice. Her innermost strength and firmness of mind is rooted in the way she vows that she will not tie her hair until she has decorated it with the blood of Dushasana (Rajgopalachari 1979). Despite being cornered Draupadi defies the odds by denying Dushasana the pleasure of humiliating her. Her vows portray her as not only powerful but as a woman filled with vengeance as well as resistance. The humiliation is the worse of its kind but she does not curse the men who are fascinated in seeing her naked clad body. She calls Krishna to rescue her. This is an interesting twist of events because Krishna comes to her rescue and her honour and dignity is restored. The notion of women as weaker and powerless is contested throughout the text of Draupadi because her 'vow show[s] the hidden and latent potential of creation and destruction possessed by a woman" (Chaudhary 2014:20). Despite all her humiliation Draupadi emerges a victor because "she has her own will, her own determination, her own capacity, and most of all her own existence" (Ibid: 20).

\section{Conclusion}

The injustices meted out to Draupadi, all justified by her marriage are inexcusable, and the legends condemning her sexuality are unreasonable. Depending how one reads the story, Draupadi can be viewed as subversive character who emerges a victor. At the end of it all Draupadi uses the same tool that is used to bring her down and instead lifts herself up. It is apparent that men play dice and wage wars in Mahabharata. However, it is the women who wield power and influence. It is the women who take decisions, direct the course of event and decide the fate of men and their generations to follow. Draupadi is that woman! Draupadi has the resilience and power that is seen as a threat to men. Draupadi's text highlights abuse of women, particularly within the family. 
In conclusion, silence disempowers women and because men know that most women would suffer in silence they continue to advance their tyrannical deeds. However, one woman, Draupadi stood her ground and voiced her disgruntlement whenever she felt wronged. That was very brave and impressive of her considering the time, place and the community she lived in. In the midst of the humiliation, torture, suffering and abuse, Draupadi found strength in herself to fight the injustices meted on to her by cruel males in a male-dominated androcentric society. It is because of that resilience and valour displayed by Draupadi that transforms her into paragon of gender and resistance.

\section{References}

Bhawalkar, Vanamala 2002. Eminent Women in the Mahabharata. New Delhi: Sharada Publishing.

Chauddhary, Preeti 2014. 'Frailty! Thy Name is Not Woman' with reference of Draupadi. BBSSES Volume 5 Issue 3. ISSN 2321-9726 [Online].

Chitra, Banerjee K 2009. The Palace of illusion. London: Pan Macmillan Ltd.

Das, Saptorshi 2014. 'Vyasa's: Draupadi: A Feminist Presentation.'International Journal of Gender and Women's Studies. June, Vol. 2, No. 2, pp. 223-231.

Diesel, Allyen 2002. 'Tales of Women's suffering: Draupadi and other Amman Goddesses as Role Models for Women', Journal of Contemporary Religion, 7: 1, 5-20. D0110.1080/1353790012098138.

Doniger, Wendy (2003). Kamasutra. Oxford World's Classics. Oxford University Press.

Falk, Nancy Auer. 'Draupadi and the Dharma.' In Gross, R. M. ed. Beyond Anthrocenticism: New Essays on women and Religion. Missoula: Scholars Press, 1977:89-114.

Ganguli Kisari Mohan 1990. The Mahabharata of Vyasa. New Delhi: Munshiram Manoharlal Publishers Pvt. Ltd. 
Mankekar, Purnima. 'Television Tales and Women's Rage: A Nationalist Recasting of Draupadi's disrobing.' Public Culture 5 (3), 1993:469492.

Nabar, Vrindar \& Shanta Tumkur 1997. Introduction, the Bhagavad Gita. Herts: Wordsworth Editions.

Neelakantan, Anand. 2013. 'Short Notes-Polyandry in Ancient India' Google Books: Leadstart Publishing Pvt. Ltd.

O'Flaherty, Wendy Doniger 1988. Textual Sources for the Study of Hinduism. Manchester: Manchester University Press:

Pattanaik, Devadutt 2010. The Common Wife Jaya: An Illustrated Retelling of the Mahabharata. New Delhi: Penguin.

Pillai, PK Narayana 1988. Sambhava Parva. Bharatham Pattu: National Book Stall.

Rajagopalachari, C 1979. Mahabharata. New Delhi: Auromene Publishers. Singh, Sarva Daman 1978. Polyandry in Ancient India. New Delhi: Vikas. Spivak, Gayatri Chakravorty1981. 'Mahasveta Devi Draupadi. trnsl.' Critical Inquiry, Vol. 8, No. 2, Writing and Sexual Difference. Winter, pp. 381-402.

\section{Online}

Dhavalikar, MK 1999-1992. 'Draupadi's Garment' Annals of the Bhandarkar Oriental Research Institute 72/73. Jstor. [Online] Available: http://www.jstor.org/stable/41694917 [Accessed 29 March 2016].

Draupadi, the Woman: Epitome of Femininity and Feminism. [Online]. Available: http://www.dollsofindia.com/Draupadi.htm. [Accessed 24 March 2016].

Ganesan, Aarathi 2014. Mahabharata: Reflections of Ancient Indian Society. [Online] Available: http://www.academia.edu/11788986/Polyandry_in_ the_Mahabharata. [Accessed 29 March 2016].

Pillai, PK 2005. Maudgalya-Nalayani Episode from Malayalam Retellings. Mahabharata Resources. [Online] 
Available: http://mahabharataresources.org/variations/mmv_maudgalya_nalayani.htm [Accessed 10 March 2016]

The Hindu Woman: Life under the laws of Manu. [Online] Available: http:// www.marked-by-teachers/gcse/sociology/the-hindu-woman-life-under-the-laws-ofmanu [Accessed 10 March 2016].

Mahabharata Book II. [Online] Available: http://larryavisbrown.homestead.com/ files/xeno.mahabsynop.htm [Accessed 21 February 2016].

— https://en.wikipedia.org/wiki/Shastra [Accessed 20 March 2016].

Valmiki Ramayana. [Online] Available: https://sanskritdocuments.org/sites/ valmikiramayan/vr_index.htm [Accessed 19 April 2017]. 